\title{
THE SYSTEM OF EU FINANCIAL INTEREST PROTECTION UNDER THE COMMON AGRICULTURAL POLICY BASED ON THE EXAMPLE OF THE PAYMENTS RELATED TO THE AREA
}

\author{
JOANNA CZAPSKA ${ }^{1}$ PIOTR WOLTANOWSKI ${ }^{2}$
}

\begin{abstract}
The Authors of this article focus on the analysis of the basic elements, which are constituting the system of the European Union financial interest' protection under the Common Agricultural Policy. The article analyzes the scope of the responsibilities of the Member States in this field, the role of the accredited paying agencies and the conditions to protect the EU interest by the European Commission as a part of the spending the funds of the CAP. There was highlighted the specific issues such as the advance payment and non-financing of the expenditure made after the deadline as the manifestations of the protection of the EU financial interest. In the paper was described the practical problems of the operation of the Integrated Management and Control System. The Authors have drawn the attention on the fundamental issues regarding the rules of the granting payments, which are fundamental in the protection of the EU interest, in that respect, there had been evaluated the legal and practical conditions to administer the administrative penalties, by detecting the irregularities and by preventing the fraud.
\end{abstract}

\section{Keywords}

EU financial interest protection; Common Agricultural Policy; control; EAGF; EAFRD

\section{JEL Classification: E62, H60, Q14}

\footnotetext{
1 Member of the Information and Organization Center for the Research on the Public Finances and Tax Law in the Countries of Central and Eastern Europe since 2017. Chief specialist at ARMA (Agency for Restructuring and Modernisation of Agriculture) since 2004. Contact email: joanna.czapska@yandex.com.

Board Member and General Secretary of Information and Organization Center for the Research on the Public Finances and Tax Law in the Countries of Central and Eastern Europe, Department of Public Finances and Financial Law, Faculty of Law, University of Bialystok. He is the author of over 50 publications in the field of tax administration, human rights, health service finance and social security. Contact email: piotrwoltanowski@ gmail.com.
} 


\section{Introduction}

The Common Agricultural Policy is the one of the oldest and most basic among the all Union policies. Work on the assumptions of this policy began in 1957 and finally came into force in 1962. The Common Agricultural policy, due to it range and importance, represents a special kind of the structural Policy and are oriented to implement the short - term, the medium - term and the long-term objectives, which growth fast and respond flexibly to the present situation on the agricultural markets, environment, agricultural producers and consumers. The action taken under the CAP is funded wholly (direct payments) or partly (the payment under the RDP) from the EU budget. The scope and the complexity of the system cause, that it requires special arrangements regarding the rigor of spending the funds, including the prevention of the unduly disbursement of fund, the excessive or inconsistent with the objectives of a program or measure, by preventing the frauds and abuse until obtaining the funds unduly collected. On the other hand, this requires to establish a certain legal and institutional framework for the distribution and reimbursement of these funds. The sectoral regulations, both at the union and the national level, include both expenditure management, the system of the sanctions and the administrative penalties, as well as the regulations regarding the recovery of the amounts unduly paid or excessively paid, the control, the monitoring and the evaluation of individual activities. In the Authors' opinion of this paper, all those regulations form contiguous, coherent and precise system, characterized by a pretty high efficiency. The functioning of this system is best to visualize by the example of the system of the direct subsidies - or, more broadly, the system of subsidies related to the area - in addition, besides the direct subsidies, there should be included the programs co-financed as agri-environmental, ecological or climate payments (Miąsik, Półtorak, Wróbel, 2012: 414).

\section{Impact of Method of Payment related to Area on EU Measures Interest Protection within Subject Scope}

The measures for the CAP implementation has been provided by Art. 40 (common agricultural markets organization) and Art. 41 TFEU (Treaty on European Union and the Treaty on the Functioning of the European Union no. 2012/C 326/01). Article 40(3) TFEU constitutes the basis for the establishment, to perform the common agricultural policy, the one or several funds for the agricultural guidance and guarantee. On 1 January 2007, pursuant to the Regulation 1290/2005, two funds were established: the European Agricultural Guarantee Fund (EAGF) and the European Agricultural Fund for Rural Development (EAFRD). The Regulation 1290 was in force until 31 December 2013, when it was repealed by the provisions 
The System of EU Financial Interest Protection under the Common Agricultural Policy...

of the Regulation 1306/2013, however, both funds were maintained. The direct subsidies are financing from the EAGF. By contrast, the EAFRD funds are intended, as the EU financial contribution of the Union to co-finance the activities under the programs of the rural development (Regulation 1306/2013, Art. 5). Both funds represent the part of the Union general budget, in which is specified the total amount of the expenditure intended to finance the normatively defined objectives of the common agricultural policy. The incomes and the expenditure of the funds are related to the implementation of the common agricultural policy and financed on the common general principles for the whole Union budget.

\section{Principles of Implementation of Budget under CAP and Union Interest Protection - Scope of Responsibilities of Member States}

The implementation of the European Union's budget rests with the Commission, which carries it out on its own responsibility and within the limits of the appropriations. However, the Member States are obligated to cooperate within the budget implementation in such a way, that the grants' appropriations used are used in accordance with the principle of sound financial management, in the transparent and non-discriminatory manner (TFEU, Art. 317). The implementation of the budget under the Common Agricultural Policy takes place within the so-called shared management with the Member States (Regulation (EU, Euratom) no. 966/2012, Art. 58). The Commission delegates the implementation of tasks under the budget to the Member States, which are required to take all necessary measures to protect the Union's financial interests. The scope of the responsibilities of the Member States, in this regard, is quite broad, and it should be assumed, that the provisions of the Financial Regulation contain only an example of an enumeration; the obligation of the Member State to take all necessary steps to protect the financial interests of the Union arises first of all from Article 325 TFEU. Thus, the Member States are required to appoint and supervise the bodies responsible for the Union financial resources management and monitoring it, to introduce an integrated management and control system, to perform duties regarding the clearing accounts and providing the information, subjecting the institutions and beneficiaries by the relevant audits and controls. In addition, the Member States are required to supervise the allocation of the funds, to impose the effective and dissuasive penalties, if they are provided by the sectoral or national legislation or to prevent, detect and correct the irregularities and the fraud, including the funds recovery, which have been unduly collected, including through the legal proceedings (Regulation (EU, Euratom) no. 966/2012, Art. 59; Regulation (EU) no. 1306/2013, Art. 58). In a simplified way, the member state's tasks could be possible to divide into the two main groups: the first, refers to the accountable and organizational part of the funds distribution, the technical 
and the organizational assistance for the whole process, and second, which refers to the material validity of the payment granting, the irregularities detection, the administrative sanctioning and reclaiming the unduly taken payments.

\section{Accreditation of Paying Agency and EU Financial Interest Protection}

The expenditures under the EAGF and the EAFRD can be covered by the Union funding only, if there have been carried out the accreditation for the paying agency (Regulation (EU) no. 1306/2013, Art. 7). This ensures the funds disbursement by the professional subjects, whom are prepared to maintain those tasks both organizationally and substantively, which reduces the risk of irregularities. The accreditation belongs to the Member State: the accredited paying agency should meet at least the requirements provided under the Union regulations, with notification of the possibility to establishing the additional criteria by the Member State. In the Republic of Poland, the role of an accredited paying agency plays the Agency for Restructuring and Modernization of Agriculture, established by the Act of 29 December 1993, regarding the Agency for Restructuring and Modernization of Agriculture establishment, currently ARMA acts under the Act of 9 May 2008. According to the Art. 6/1/1, the ARMA implements, among the others, the tasks related to the direct payments and the rural development defined in the regulations applicable to a given type of the payment. As a typical executive agency, it is the state legal entity, functioning as an element of the public finance (Ruśkowski, Salachna, 2014: 214). At the margins, it is worth to mention, that till 1 September 2017, there was exiting the second paying agency, Agricultural Market Agency, established under the law of 11 March 2004 regarding the Agricultural Market Agency and some other organization of the agricultural markets. On 1 September, the AMA has been decommissioned, and its tasks has been assumed by the ARMA. Meanwhile the part of these tasks has been delegated to the established at the same day the National Centre of the Agriculture Support, but apart from the payments executions and the execution of the undue aid amounts. These amendments were within the respect of the provisions of the Regulation 1306/2013, and partly constitute its execution (e.g. regarding the administrative service costs reduce), but in practice the competence allocation in some cases could cause some controversies. However, it's not applicable to the field of the payments, where the granting is continuing to be within the limits of the competence of the Agency of Restructuring and Modernization of Agriculture. The competent minister of the public finances decides about the granting and withdrawing of the accreditation, as the coordinating unit provides the informing about the granting of the accreditation to the Commission. The accreditation is preceded by an internal 
The System of EU Financial Interest Protection under the Common Agricultural Policy...

audit inspected by an external audit body. In particular, the audit includes these elements of the paying agency's function, for which exist the procedures intended to approve and execute the payments, the security of the information systems as well as their scope, in which existing procedures and systems are able to protect the Union budget, in this, based under the risk analysis measures able to prevent the financial frauds. The information regarding the accreditation is provided to the European Commission. Additionally, besides the constant supervision of the competent minister responsible of the public finances over the paying agency, every three years the certification body carried out the revision of the given accreditation. Currently, the role of the certification body is performed by the Head of the National Revenue Administration, who is performing his tasks in accordance to the Act of 16 November 2016 regarding the National Revenue Administration. Therefore, the authority to accredit, certify and supervise the paying agency rest on the institutions of a Member State. Whereas, that the given accreditation covers, among others, the inspection of the existing payment systems and the procedures, including, in terms, the protecting of the Union budget and risk-based anti-fraud measures, by checking compliance with the accreditation conditions constitute as the Member State's obligations to protect the Union's financial interest. The European Commission can apply to the Member State to withdraw the accreditation, if the paying agency does not meet the accreditation requirements and did not amend the deadline, if the recovery plan is not implemented by the Member State, or, if the paying agency act without accreditation. The Commission authority also include the adoption of delegated and the implementing acts, which are necessary to protect the Union's financial interests. The Commission also has an impact on the audit, including the setting of the guidelines. Within this construction of the audit mechanism of the paying agency, it is not possible to rule out the discrepancies in the positions regarding the accreditation criteria fulfillment. However, the final decision, in this respect, belongs to the Commission, which having due to protect the Union financial interests, can question the settlement of the expenses made by the agency, which doesn't meet the accreditation requirements.

\section{The system of Funds Payment by European Commission under EAGF and Contribution under the EAFRD in the context of the Protection of the EU Financial Interests}

The expenditure under the EAGF completed by the accredited paying agencies shall be borne by the Commission in the form of monthly payments, on the basis of the declaration of the expenditure presented by the Member State. The expenditure included in the declaration should correspond to the expenditure actually incurred by the paying agencies, it should also be done at the specific periods, in accordance, 
with the procedures and following all relevant controls, including the administrative and on-the-spot checks. The Commission, after acceptance of the declaration, shall transfer the appropriate resources reduced by the potential corrections or other deductions to the account carried out by that Member State. These funds are transferred after to the paying agency's account based on the request from the competent minister for the rural development, in accordance, with the submitted need made by the paying agency. The funds allocated for the implementation of the national contribution, in the case of co-financed payments (EAFRD), are transferred by the competent minister for the rural development in the form of the designated subsidy. Whilst, in the case of the EAFRD, the Commission after the decision on the approval of the rural development program, transferred the pre-financing amounts in the form of the annual payments from $1 \%$ to $1.5 \%$ of the total amount of the support, however under the condition, that the Member State will starts using them within 24 months from the date of receiving the first refinancing, under the rigour of the repayment. The remaining part of the resources as the contribution from the Commission shall be transmitted within 45 days after the submission of the relevant declaration by the Member State. The funds recovered by the Member State are deductible and can be re-used under that fund. The financing and accounting of the expenditure under the EAFRD is carried out separately within the each activity. In the case for both Funds, the Member State is obliged to submit both the annual clearance of the expenditure of the paying agency and the declaration of the expenditure for the following year within a specified period. The above mechanism is limited by the numerous Commission's powers concerning the cessation, the suspension, the clearance and the correction of the payments, including also the duty to provide the information by the Member State. The Commission may postpone the monthly payments under the EAGF, if the information provided by the Member State in the statement of the expenditure or the need raises doubts, questions or require the clarification (Commission Delegated Regulation (EU) no. 907/2014, Art. 9). Additionally, the Commission may suspend the payments for the both Funds in the case, if the information was not provide on time regarding the checks carried out on the aid application and the and payment applications (Regulation (EU) no. 1306/2013, Art. 42; Commission Delegated Regulation (EU) no. 907/2014, Art. 10). It should also be noticed, that the postponement, the cessation or the suspension of the payment, relatively the refusal of the financing shall not refer to the results against the beneficiaries: in the case of the late payment of benefits or the refusal of the funding for the beneficiaries, the payments are covered from the Member State's funds, and more precisely the obligation of the payment falls on the accredited paying agency. The system of the funds withdrawing and the clearing the accounts has been structured in such a way to secure the European Union financial interest in the best way. The system is supplemented by the Commission powers related to the possibility of carrying out the controls and the issuing of the delegated and the 
The System of EU Financial Interest Protection under the Common Agricultural Policy...

implementing acts. However, this system demonstrate certain flexibility, because the Member States have the possibility to supplement the provided before information and documents, the application adjustment, abundantly including the submission of explanations and the corrective procedure (Regulation (EU) no. 1306/2013, Art. 52). The Commission has also the right to moderate the amount of the correction, which depends on the gravity of the irregularity - here the assessment criterion is the significance of the risk of losses for the Union budget. This allows each situation to treat separately and considerably by enhancing the efficiency of the entire system.

\section{Advance Payment and EU Financial Interest Protection under CAP}

Particular payment installments are further reduced due to the payments made before or after the payment deadline (Regulation (EU) no. 1306/2013, Art. 75) which are not the subject to be financed, under the provision to pay the advance payment through the direct payments and the RDP. In 2017, the Republic of Poland benefited from this right, and from 16 October $70 \%$ of the advance payments were paid to the farmers. The advance payments are paid following the administrative inspection and in the case of those applications, where was not detected the mistakes. However, in practice, the advance payment would be possible to treat as a certain exemption from the system's integrity in terms of the Union's financial interest protection. Although the advances payment should occur only after the administrative inspection of the application and when no irregularities were detected, however, due to the period of the advance, the probability of the undue or the excessive payment is slightly higher than in respect to the period of the major payment. In the case of the advance payments, therefore, the difficult situation in the agriculture and the necessity of the rapid improvement of the financial situation of the farmers was prevailing the factor over the protection of the Union's financial interest.

\section{Integrated Administration and Control System and EU Interest Protection under CAP}

The payments related to the area are granted to beneficiaries after the appropriate administrative inspection including, inter alia, cross-checks and the on-thespot inspections. The Member States are obliged to carry out the administrative inspection of each application, although the on-the-spot inspection is not required in all cases. Both, the administrative inspections as well as the payment calculations are carried out under the support of the communication and 
information system so-called the Integrated Management and Control System. The system is a computerized database, where is recorded the data obtained from the applications for assistance and the payment applications with regard to each beneficiary of the support, in addition, the database allows to acquaint with the detailed data from the previous ten years. In addition, the system identifies each agricultural parcel, the registration and the identification of the payment entitlements allow to carry out the administrative inspection, by including the cross-checks inspection comparing to other applications, as well as with other areas and the other assistance programs. The system allows to verify each application, grant the payments, impose the administrative penalties or reduce, and in addition, count the payments. It is fully justified to burden the Member States with the obligation to construct and implement such system: on the one hand, the system enforces the equal treatment of beneficiaries, in particular, as to the application of the granting payments, reductions, the administrative penalties and the deadlines, the partial automation, and, hence, also the acceleration and the reduction of the administrative payments costs, which is particularly important for the direct payments and for the agri-environment payments, due to the widespread participation of the producers into these programs. On the other hand, the system increases the level of the Union's financial interest protection by facilitating the detection and the prevention of the irregularities as well as the double financing. The registration of beneficiaries, the applications, and the agricultural parcel, prevents the duplication of the applications, by applying for the payments to the same parcel by various beneficiaries, which are not compliant with the conditions of the individual programs or there is the infringement of the requirements as regards to the good agricultural culture. The system also facilitates the detection of the fraud, including, in particular, the cases of the circumvention of the law to obtain the payment. The system also enables the precise monitoring of the level of spending of funds during their payment to beneficiaries.

The disadvantage of the integrated management and the control system is its size and complexity. The system is a subject of the evaluation and ongoing updates, related to these responsibilities, as well as the maintenance of the system rests on the Member State. The European Commission attaches the great importance to the effective functioning of the systems of the separate Member States, what manifests, inter alia, among others liabilities of the Member States require to provide the annual evaluation reports of these systems. It should be noticed, that the negligence of the Member State regarding the functioning of the system, can affect by the imposing of the severe financial corrections up to the partial exclusion from the funding. 
The System of EU Financial Interest Protection under the Common Agricultural Policy...

\section{Rules for Granting Payments and EU Interest Protection under CAP}

The European Union's financial interests protection in the field of the Common Agricultural Policy does not focus only on the institutional aspects of spending funds: equally important are the regulations concerning the rules for their granting provided by the Union regulations and, in the case of the EAFRD, the national as well. The structure of the participation in the individual programs aims to minimize the risk of the irregularities as well as the improper use of the funds, including the reductions and the administrative penalties. The entire is completed by an effective system of the recovery the unduly or the excessively collected payments. The rules for the granting of the payments under the direct support systems was directly concluded in the provisions of the Regulation no. 1307/2013, moreover in the national regulations, in the Act regarding the payments under the direct support system hereinafter referred to as the Act of the OB and the regulations issued on that basis. In the case of the direct payments, the act based on it regulations are clarified only by the Union's provisions.

The direct payment is the base payment, which includes the widest possible circle of the group of the recipients within the whole Union. The rules and the schedules for the granting of these payments are harmonized, which facilitates management and the equal treatment of beneficiaries. In respect of the rate, the Republic of Poland demanded in the negotiating process align them with the other member states. However, this process was introduced gradually. The rate of the direct payments for the 1 ha after the reform of the Common Agricultural Policy in 2014, has been lowered and now the amounts are 461.55 PLN.

The detailed discussion regarding the rules of the granting of each of these payments exceeds the scope of this study, however, it is worth, in terms of the Union's financial interest protection to draw the attention of these aspects such as the introduction of the financial discipline, the limiting of the upper amount of the payments by introducing the concept of the relatively understanding of the active farmer.

The financial discipline maintenance involves the introducing of the reduction coefficient of the payment, in the situation, where, according to the forecasts for a given year, the payment limits will be exceeded. The reduction coefficient is defined as a percentage and applies to the payments by exceeding the total amount of 2,000 EUR. The obtained provision in this way constitutes to be secure, in a case, when the limit of the funds was exceeded for a given budget year. If this limit was not used, the funds are returned to the beneficiaries (the final recipients) which were collected from them - wholly or partially. This is a very interesting mechanism, 
which aims to maintain the balance of the Union's budget in regards to the direct payments. It should be emphasized, that the reduction concerns only the highest amounts of the payments, which is compatible with the objectives of the direct payments, to whom shall include the increase of the income of the agricultural farms, however, it cannot exceed a certain framework. The public funds obtained under this program constitute the aid, however, they should not constitute a source of the excessive profit for the farmers.

In a similar way should be evaluated the reduction of the amount of the direct payments, which is above the total amount of 150 thousand EUR for one beneficiary. However, here the Commission has left the way to adjust the amount of the aid, in the case, if there will be applying for it the particularly large collective entity; it cannot be excluded the occurrence for the payment by the organizations associating the farmers indeed.

In 2014 was introduced the concept of the active farmer. According to Regulation 1306/2013, Art. 9, the direct payments cannot be granted to the farmers, whose agricultural lands consists mainly of the persisting naturally lands, which are suitable for the grazing or cultivation activities, and whose farmers do not carry out the minimum activities defined by the Member States on those areas. The financing has also excluded the entities, which operate the airports, the water pipes, the permanent sporty and the recreational areas, as well as provide the rail transport or real estate services. This solution has a flexible character - on the one hand, it prevents the granting of the payment contrary to their purpose, as well as incompatible with the objectives of the Common Agricultural Policy for the entities, who do not provide the agricultural activity. On the other hand, it is enabled for such entities to obtain the payments, when they will be able to prove, that agricultural activity is the main source of their income, as well the main object of the activity. It should be noticed, that as the part of the review of the CAP, which took place in 2016, and the changes planned for this reason, it was decided not only to maintain the concept of the active farmer, but also to extend the concept of the farmers towards being the subject of the social insurance and the subject, who pays the taxes.

\section{Possibility to Impose Administrative and EU Interest Protection under CAP}

Preventing the irregularities is also encouraged by the possibility to impose the administrative penalties and deductions on farmers if the beneficiary does not meet the eligibility criteria, the liabilities or other obligations related to the granting aid 
The System of EU Financial Interest Protection under the Common Agricultural Policy...

or support. The administrative penalties are imposed, if they have been provided in the Union sectoral law, or in the case of the funds payable through the EAFRD, also national, independently of the refusal to grant or to impose the obligation to return the unduly paid aid.

The administrative penalties may take the form of reduction of the amount of aid or the support of the payment in relation to the support application or the payment application, where have been detected the non-compliance or in regard with the subsequent applications; disbursement of the amount of aid based on its size or period, which non-compliance refers to, exclusion from the right to participate in a given aid scheme or in support measure. The penalties should be proportional and calculated by taking into account the scope, the durability, the severity and the repeatability. The penalties should be also effective and dissuasive particularly, and the aim of their implementation, first of all, is to encourage beneficiaries to comply with the principles of the adopted programs and the liabilities. The construction of the provisions governing the granting of the payments fits into the system of the EU's financial interests protection, mainly, by reducing the possibility of the irregularities perpetrated by the beneficiaries or relative their prevention through the launched system of the administrative penalties.

\section{Detection of Irregularities and Recovery Undue or Unduly Taken Granting EU's Financial Interest Protection}

The irregularities detection and the fraud preventing is one of the most basic ways to protect the European Union financial interests. It is combined with the issue of the funds recovering, which was paid unduly or in the excessive amounts.

The general principles regarding the detection and the elimination of the irregularities and the recovery of the amounts unduly and excessively collected have been laid down in the Regulation 2988/95. According to the Art. 1/2 of that regulation, irregularity means any infringement of provision of the Community law arising out of an act or omission from the economic subject, that caused or could cause damage to the general budget of the Communities or the budgets, that are managed by the Communities or by the reducing or losing the revenue, which comes from own resources and collected directly on behalf with the Communities, or as an result with the unjustified expenditure. The regulation lays down the general rules of the financial interest protection, and, therefore, applies to the Communities, in case of the payments related to the area, the cited definition should be referred to the Union budget. 
Therefore, the irregularity is related to the act or negligence of the payment's beneficiary, which caused damage to the Union budget, either, by reducing or losing the revenue or by the unjustifiable expense, which should be related to the funds received unduly or in excessive amounts. It is debatable, whether the mere possibility of the harm is sufficient for the existence of an irregularity, and therefore, the situation, where this effect has not occurred. Under the principle of the Art. 2/1, point $g$ of the regulation $1306 / 2013$, this definition applies to the payments paid from the EAGF and to the assistance co-financed by the EAFRD.

The mechanism of recovering the unduly or the excessively collected payments is one of the most important elements of the European Union's financial protection system. The basis for its operation are the EU regulations, however, at the national level are using properly the existing procedures, which not only eliminates the costs associated with the implementation of a completely new system, but also due to the use of existing tools is characterized by high efficiency, which should be assessed positively due to their multiplicity and the high level of complexity of the aid programs.

As a general rule, the irregularity entails the need to return of the unlawfully obtained benefit with the relevant interest. In addition, the payments cannot be granted to beneficiaries, who artificially created the conditions to receive the payment. The risk related to the impossibility of the recovering the amount of unduly collected payments is half-burdening the Union and the Member State. The similar is in the situation when the amounts of support were wrongly recovered. The settlement of expenses does not relieve the Member State from the obligation to continue the proceedings to recover the undue payments. The Member State shall ask beneficiary for a refund of the amount to prevent any irregularity or negligence within the 18 months after the approval or receipt by the paying agency of an audit report or similar document stating that the irregularity has taken place.

In the Republic of Poland, the ARMA is the authority as the accredited paying agency, which is responsible to determine and recover the unduly collected payments. The determination of the amount of the unduly or the excessively collected payments takes place by a decision of the competent ARMA authority when the administrative procedure occurred. The proceedings have the independent character, the separation from the procedure of granting the payment; it is assumed, that, in order, to determine the amount of the unduly collected payments, it is not necessary to eliminate the legal decision of granting the payment from the turnover.

The receivables due to improperly or excessively collected funds are applied under the provisions of Sec. III of the Act of 29 August 1997 the Tax Ordinance, The enforcement proceedings in the administration is applied to the enforcement of 
The System of EU Financial Interest Protection under the Common Agricultural Policy...

these claims, which are applying the administrative enforcement proceeding. The tax authority is the competent authority to issue the decision on the determination of the unduly paid or the overpaid payments. The execution of that liabilities is using the proceedings in the administration to enforce these claims.

The provisions, relating to the recovery of the amounts the unduly or the overpaid payments cross the group of the entities, against which the amount of the claim may be fixed. Here may be applied the provisions of the Tax Ordinance Act. However, the very interesting solution is provided under the Art. 29/1a of the Act on the ARMA, according to which, the possibility to determine the amount of the unduly or the excessively collected payments also refers to the entities, which are not the parties of the proceedings for the granting payments or the financial aid, who have drawn the public funds the unduly or the excessively. This provision applies to the situation, that is often in practice when the funds have been transferred to the bank account of a farmer, who has died or was wound up and then has been taken from the account by the third parties, those are not the successors or the legal successors. By extending the group of the entities to these persons, it makes possible to recover an improperly obtained benefit also from the persons, who acquired the funds from the bank account, however, they were neither able to be parties of the procedure for granting the payment and, in consequence, in another situation, the recovery of the acquired funds through administrative proceedings would not be possible. It should be noticed, that this provision does not seem to apply to the bank, that collected such funds, because its role is limited to maintain a party's account, which, of course, does not completely exclude the probable compensative responsibility of the bank, if, for example, the account was disbursed by an unAuthorized person.

For the specific mechanisms regarding the recovery of the unduly or the excessively collected payments, should also be included the possibility of the amounts deduction, which were determined by the decision from an indisputable and due claim or receivables, due to payments from the pursued by the Agency payments under the individual the European Union funds and the national public funds intended for the co-financing the expenses undertaken from these funds.

The deductions are made by a declaration submitted to the debtor in written form, it has the retroactive effect from the moment when it became possible. Similarly, the costs, which have been arisen from the recovery of claims and the receivables, can be also deducted. This solution, significantly facilitates the recovery of the funds, which were collected the unduly or the excessively without the need to conduct the separate enforcement order proceedings, although, it seems, that in practice, certain doubts may arise regarding the area of the payments, by setting the time to determine the entitlements, for example, in the case, when the court-administrative proceedings are taking the place in this issue. 


\section{Conclusions}

The presented, in brief, the payment mechanisms related to the area under the Common Agricultural Policy illustrate how wide is the range of the activities necessary to protect in a proper way the European Union financial interests in this field. The scope and the complexity of this policy forces to use the appropriate measures to protect it. The cohesive, tight system, which would allow the proper protection of the European Union interests, would not, however, be possible without close cooperation between the Member States, both, as on the institutional and the legislative level.

At the same time, this system is not perfect - it is characterized by the high dynamics, it is the subject of the constant modifications, aiming to provide the best possible protection. The current ongoing reform of the payment system arises from the review of the payment system under the EAGF and the EAFRD, which occurred in 2016, by aiming to simplify the payment distribution system, will have an impact on the functioning of the presented mechanisms. Similarly, there should be evaluated the shape of the discussion regarding the CAP after 2020.

\section{References}

Miąsik, D., Półtorak, N., Wróbel, A.: Traktat o funkcjonowaniu Unii Europejskiej (Treaty on the Functioning of the European Union), Warszawa: Wolters Kluwer, 2012.

Ruśkowski, E., Salachna, J. (eds.): Finanse publiczne. Komentarz praktyczny (Public Finances. Practical comment), Gdańsk: ODDK, 2014.

EU: Treaty on the Functioning of the European Union: no. 2012/C 326/01.

EU: Commission Delegated Regulation (EU): no. 907/2014 supplementing Regulation (EU) no. 1306/2013 of the European Parliament and of the Council with regard to paying agencies and other bodies, financial management, clearance of accounts, securities, and use of euro.

EU: Council Regulation (EC): no. 1290/2005 on the financing of the common agricultural policy.

EU: Council Regulation (EC, Euratom): no. 2988/95 on the protection of the European Communities financial interests.

EU: Regulation (EU): no. 1305/2013 of the European Parliament and of the Council of 17 December 2013 on support for rural development by the European Agricultural Fund for Rural Development (EAFRD) and repealing Council Regulation (EC).

EU: Regulation (EU): no. 1306/2013 of the European Parliament and of the Council of 17 December 2013 on the financing, management, and monitoring of the common agricultural policy and repealing Council Regulations (EEC). 
The System of EU Financial Interest Protection under the Common Agricultural Policy...

EU: Regulation (EU, Euratom) no. 966/2012 of the European Parliament and of the Council of 25 October 2012 on the financial rules applicable to the general budget of the Union and repealing Council Regulation (EC, Euratom) no. 1605/2002.

PL: Act of 16 November 2016 on National Revenue Administration, as amended.

PL: Act of 5 February 2015, on payments under the direct support system, as amended.

PL: Act of 9 May 2008, on the Agency for Restructuring and Modernization of Agriculture, as amended.

PL: Act of 11 March 2004 on the Agricultural Market Agency and some other organization of the agricultural markets, item, as amended.

PL: Tax Ordinance Act of 27 August 1997, as amended.

PL: Act of 29 December 1993 on the Agency for Restructuring and Modernization of Agriculture, as amended. 